\title{
Establishing a TaqMan-Based Real-Time PCR Assay for the rapid detection and quantification of the newly emerged duck tembusu virus
}

\author{
Liping Yan, Pixi Yan, Jiewen Zhou, Qiaoyang Teng and Zejun Li*
}

\begin{abstract}
To establish an accurate, rapid, and a quantifiable method for the detection of the newly emerged duck Tembusu virus (DTMUV) that recently caused a widespread infectious disease in ducks in China, we developed a TaqManbased real-time PCR assay by using E gene-specific primers and a TaqMan probe. This real-time PCR assay was 100 times more sensitive than the conventional PCR. The reproducibility and specificity of the real-time PCR assay were confirmed using plasmids containing E genes or RNAs and DNAs extracted from well-known viruses causing duck diseases. The reliability of this real-time PCR assay was confirmed in 19 of the 24 swab samples, 22 of the 24 tissue samples collected from experimentally infected ducks, as well as 15 of the 21 clinical samples collected from sick ducks since they were verified as DTMUV-positive. The results reveal that the newly established real-time PCR assay might be a useful diagnostic method for epidemiologically investigating and closely observing the newly emerged DTMUV.
\end{abstract}

\section{Introduction}

In April 2010, an outbreak of the newly emerged duck Tembusu virus (DTMUV) caused a range of symptoms in infected ducks, including retarded growth, high fever, loss of appetite, decreased egg production, and death. The outbreak was first detected in southeast China, including the Shanghai, Zhejiang, Jiangsu, Fujian, and Anhui provinces and continued until the winter [1-3]. Shelducks in the provinces of Shandong, Henan, Hunan, Hubei, and Jiangxi were under a huge threat by this newly emerged virus with $100 \%$ infection and morbidity rates and mortality rates from $5 \%$ to $30 \%$. To date, more than 10 million shelducks have been infected, and approximately 1 million have died. However, being a novel emerged causative agent in ducks, the lack of fast, easy, and reliable methods to diagnose the disease has limited researchers' abilities to conduct epidemiological investigations and monitor DTMUV. In this paper, we described a TaqMan-based real-time PCR assay for this newly emerged virus.

\footnotetext{
* Correspondence: lizejun1230045@yahoo.com.cn
Division of Avian Infectious Diseases, Key Laboratory of Animal Parasitology

* Correspondence: lizejun1230045@yahoo.com.cn
Division of Avian Infectious Diseases, Key Laboratory of Animal Parasitology of the Ministry of Agriculture, Shanghai Veterinary Research Institute, Chinese Academy of Agricultural Sciences, 518 Ziyue Road, Minhang District, Academy of Agricultural
Shanghai 200241, China
}

\section{() Biomed Central}

\section{Materials and methods}

\section{Primers and probe design}

Specific primers and a TaqMan probe to detect DTMUV were designed using Primer Express 2.0. The target sequence (115-bp long) was selected from a relatively conserved region on the E gene of DTMUV, Fengxian virus (FXV) strain (GenBank accession no. HQ833330). The fluorescent reporter dye, FAM, was located at the 5' end of the probe; the quencher, TAMRA, was located at the 3' end. The primers used were the EF primer (forward, 5'-TGTCTTATGCAGGTACCGATG-3') and the ER primer (reverse, 5'-CGTATGGGTTGACTGTTA TCA-3'). The probe used was the TaqMan probe EP (FAM-AGTTCCCATATCCATGTC-TAMRA).

\section{Viruses}

FXV, one of the DTMUV isolates, was propagated in specific pathogen-free embryonated chicken eggs. The embryos were carefully monitored, and those that died 24$120 \mathrm{~h}$ post-inoculation were pooled, homogenized, and centrifuged along with the chorioallantoic membranes. The supernatants were stored at $-80^{\circ} \mathrm{C}$ until they were used for molecular analyses. The FXV titer was determined according to the $50 \%$ egg lethal dose $\left(\mathrm{ELD}_{50}\right)$. 


\section{RNA extraction and reverse transcription}

RNA was extracted from FXV by using the RNeasy mini kit (Qiagen Inc., Valencia, CA) according to the manufacturer's instructions. The total RNA was stored at $-80^{\circ} \mathrm{C}$ until use.

First-strand cDNA was synthesized using AMV reverse transcriptase (TaKaRa Biotechnology, Dalian, China) according to the manufacturer's instructions. Briefly, the following reagents were added and mixed: $4 \mu \mathrm{L}$ of $5 \times$ reverse transcriptase buffer, $2 \mu \mathrm{L}$ of dNTP mixture (10 $\mathrm{mmol} / \mathrm{L}), 1 \mu \mathrm{L}$ of random primer $(50 \mathrm{mmol} / \mathrm{L}), 2 \mu \mathrm{L}$ of AMV reverse transcriptase, $0.5 \mu \mathrm{L}$ of RNAase inhibitor (40 U/ $\mu \mathrm{L}$ ), $5 \mu \mathrm{L}$ of total RNA, and $5.5 \mu \mathrm{L}$ of RNAase-free water. The reaction mixture was sequentially incubated at $42^{\circ} \mathrm{C}$ for $60 \mathrm{~min}$ and then at $72^{\circ} \mathrm{C}$ for $15 \mathrm{~min}$. The DNA was subsequently stored at $-20^{\circ} \mathrm{C}$.

\section{Preparing the standard plasmid DNA}

PCR was used to amplify the E gene in a reaction mixture consisting of $5 \mu \mathrm{L}$ of $10 \times$ buffer, $4 \mu \mathrm{L}$ of dNTP, $2 \mu \mathrm{L}$ of each primer (10 $\mu \mathrm{M}$ of EF and ER), and $0.5 \mu \mathrm{L}$ of Ex Taq Hot Start (TaKaRa Biotechnology, Dalian, China). The thermal conditions were as follows: initial denaturation at $94^{\circ} \mathrm{C}$ for $5 \mathrm{~min} ; 35$ cycles at $94^{\circ} \mathrm{C}$ for $30 \mathrm{~s}, 55^{\circ} \mathrm{C}$ for $30 \mathrm{~s}$, and $72^{\circ} \mathrm{C}$ for $30 \mathrm{~s}$; and a final extension at $72^{\circ} \mathrm{C}$ for $10 \mathrm{~min}$.

The PCR product was then inserted into a pMD18-T vector, (TaKaRa Biotechnology, Dalian, China). After the recombinant plasmid was amplified in $\mathrm{DH} 5 \alpha$ host bacteria, it was purified using a commercial test kit (Axygen Scientific Inc., Union, CA). The concentration of the plasmid was determined according to the $\mathrm{OD}_{260}$ value, and the number of copies of the plasmid was calculated [4]. The plasmids were maintained at $-20^{\circ} \mathrm{C}$ for use as standard DNA in subsequent experiments.

\section{Establishing a standard curve for the real-time PCR}

The real-time PCR for the E gene was conducted in a $25 \mu \mathrm{L}$ reaction system containing the following ingredients: $2.5 \mu \mathrm{L}$ of $10 \times$ buffer, $2.5 \mu \mathrm{L}$ of dNTP, $1 \mu \mathrm{L}$ of each primer $(10 \mu \mathrm{M}$ of EF and ER), $0.6 \mu \mathrm{L}$ of the probe $(10 \mu \mathrm{M}$ of EP), $1 \mu \mathrm{L}$ of recombinant plasmid, $0.2 \mu \mathrm{L}$ of Ex Taq Hot Start, and $16.2 \mu \mathrm{L}$ of sterile water.

Real-time PCR was performed on Mastercycler ep realplex (Eppendorf, Germany) by using the following thermal cycles: $95^{\circ} \mathrm{C}$ for $2 \mathrm{~min}, 40$ cycles at $95^{\circ} \mathrm{C}$ for $20 \mathrm{~s}$, and $54^{\circ} \mathrm{C}$ for $1 \mathrm{~min}$. The assay was repeated at least 3 times with each template and the negative control.

\section{Determining the specificity of the real-time PCR}

To determine the specificity of the real-time PCR, the FXV and 5 well-known viruses causing infectious diseases in ducks, including duck plague virus (DPV), avian influenza virus (AIV), duck hepatitis virus (DHV), duck parvovirus (DPVV), and Newcastle disease virus (NDV), were tested under the conditions described above.

\section{Sensitivity of the real-time PCR}

To determine the lower detection limit, the plasmid stock was diluted with sterile water to $5 \times 10^{7}$ copies $/ \mu \mathrm{l}$, $5 \times 10^{6}$ copies $/ \mu \mathrm{l}, 5 \times 10^{5}$ copies $/ \mu \mathrm{l}, 5 \times 10^{4}$ copies $/ \mu \mathrm{l}, 5$ $\times 10^{3}$ copies $/ \mu \mathrm{l}, 5 \times 10^{2}$ copies $/ \mu \mathrm{l}, 5 \times 10^{1}$ copies $/ \mu \mathrm{l}$, and $5 \times 10^{\circ}$ copies/ $\mu$ l. Four replicates of each dilution and 2 negative controls (blanks) were then tested by the real-time PCR and conventional PCR.

\section{Reproducibility of the real-time PCR}

To test the reproducibility of the real-time PCR, standard plasmids in 3 different concentrations $(5 \times$ $10^{5}$ copies $/ \mu \mathrm{l}, 5 \times 10^{4}$ copies $/ \mu \mathrm{l}$, and $5 \times 10^{3}$ copies/ $\mu \mathrm{L}$ ) were aliquoted and stored at $-80^{\circ} \mathrm{C}$ for future use as templates for intra- and inter-assay comparisons. The variations in the inter-assay were assessed by testing 5 replicates of each concentration in a single round of real-time PCR, and the variations in the intra-assay were assessed by repeating 5 rounds of real-time PCR. The coefficients of variation $(\mathrm{CV})$ for the $C \mathrm{t}$ values of the intra- and inter-assay comparisons were determined.

\section{Detecting samples from experimentally or naturally infected ducks}

The shelducks were inoculated intranasally with $10^{5}$ $E D_{50}$ of the virus in $0.2 \mathrm{~mL}$ of supernatant of homogenized embryos and chorio-allantoic membranes of eggs that died 24-120 h post-inoculation with FX2010. One day after they were inoculated, 2 contact ducks were introduced into the isolator and placed among the ducks that had been inoculated intranasally. Oropharyngeal and cloacal swabs were collected from all ducks on days 2,3 , and 5 post-inoculation. All swabs were suspended in $1 \mathrm{~mL}$ of phosphate-buffered saline (PBS) and used for RNA extraction with an RNeasy Mini kit (Qiagen) or virus isolation. Two ducks from the inoculated group were euthanized 4 and 7 days post-inoculation, respectively. Two contact ducks were euthanized 6 days post-contact, and 2 non-infected ducks were euthanized as negative controls. Samples of blood, liver, spleen, kidneys, heart, brain, pancreas, and lungs were collected from the euthanized ducks. The samples were weighed, homogenized, and diluted in PBS ( $\mathrm{pH} 7.4)$ at a ratio of 1:1 (mL/g). A portion of each sample was used for total RNA extraction and applied to the reverse transcriptase real-time PCR assay. In addition, a portion of each sample was used to isolate the virus in embryonated chicken eggs. 
Twenty-one clinical samples, including blood, spleen, liver, and brain samples, from sick farm-raised ducks suspected of being infected with DTMUV were tested using both real-time PCR and conventional PCR.

\section{Results}

\section{Establishing a standard DNA template}

The concentration of the original extract of the recombinant plasmid containing the FXV E gene was $154.39 \mathrm{ng} / \mu \mathrm{L}$. Accordingly, the extract contained $5.00 \times 10^{10}$ plasmids $/ \mu \mathrm{L}$.

\section{Establishing a standard curve for the real-time PCR}

The standard curve was generated using different template concentrations ranging from $5.00 \times 10^{7}$ to $5.00 \times 10^{1}$ copies $/ \mu \mathrm{L}$ obtained by 10 -fold serial dilutions. The assays were linear with $R^{2}$ values of 0.998 ; the reaction efficiency for the $\mathrm{E}$ gene was $97 \%$ (Figure 1).

\section{Real-time PCR specificity}

The FXV and 5 different duck-causative agents of duck infectious diseases were tested using the real-time PCR. FXV tested positive, while the other virus samples (i.e., DPV, AIV, DHV, DPVV, and NDV) and the water control tested negative (Figure 2).

\section{Real-time PCR sensitivity}

The detection limit of the real-time PCR was 50 copies, while the conventional PCR assay showed positive results only when more than $5 \times 10^{3}$ copies of the template were used (Figure 3B). Therefore, the sensitivity of the realtime PCR is about 100 times greater than that of conventional PCR.

\section{Reproducibility of the real-time PCR}

When the 3 different concentrations of plasmids were subjected to the real-time PCR assay, the intra- and inter-assay $\mathrm{CV}$ values (i.e., the means from each of 5 replicates) were relatively small (Table 1 ).

\section{Detecting DTMUV in the samples from artificially and naturally infected ducks}

Twenty-four swab samples were collected from the ducks inoculated intranasally with FXV and those in contact with infected ducks. When the swabs were tested by the real-time PCR, 19 of them were DTMUVpositive; 7 of these were positive according to virus isolation (Tables 2 and 3).

Regarding blood and tissue samples, the positivity rate of all samples by the real-time PCR was obviously higher than by virus isolation. Specific RNAs of the DTMUV E gene were detected in all liver and kidney samples by the real-time PCR; meanwhile, only 2 of the 4 liver samples and 3 of the 4 kidney samples were DTMUV-positive by virus isolation (Table 4). More than $10^{4}$ copies of specific DTMUV RNA were detected in all samples determined to be DTMUV-positive by virus isolation. In addition, the samples from noninfected ducks produced negative results when tested by both real-time PCR and virus isolation.

To determine the causative agents of disease in farmraised ducks, 21 clinical samples collected from sick ducks were tested by real-time PCR and conventional PCR. Of these, real-time PCR showed that 15 were DTMUV-positive, while conventional PCR showed that only 11 were DTMUV-positive.

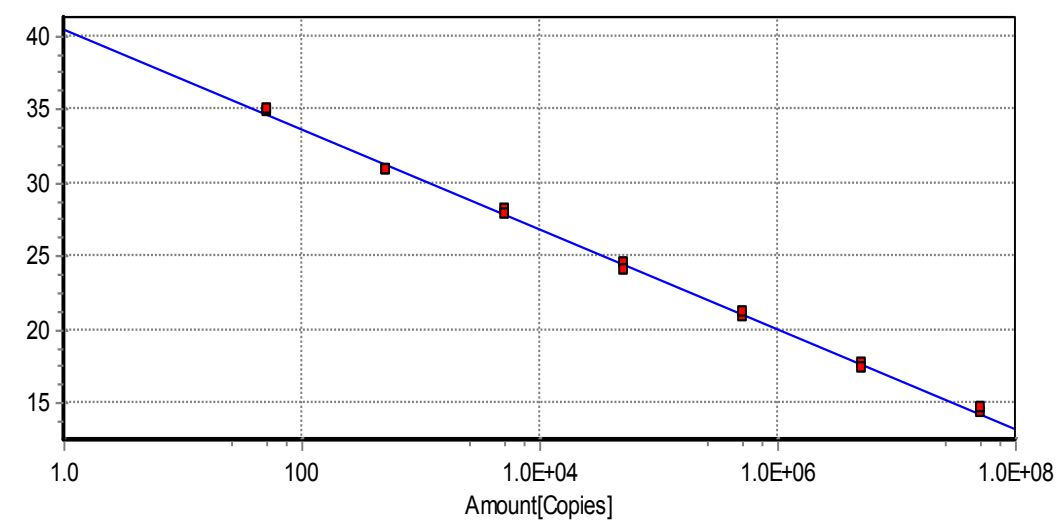

$\begin{array}{ll}\text { Slope: } & -3.395 \\ \text { Y-Intercept: } & 40.47 \\ \text { Efficiency: } & 0.97 \\ \text { R^2: } & 0.998\end{array}$

Figure 1 Standard curve for the real-time PCR. The X-axis represents copies of the plasmids, and the Y-axis represents the cycle threshold $(C t)$. The assays were linear from $10^{7}$ to $10^{1}$ template copies; $\mathrm{R}^{2}$ was 0.998 , and the reaction efficiency was $97 \%$ for the $\mathrm{E}$ gene. 


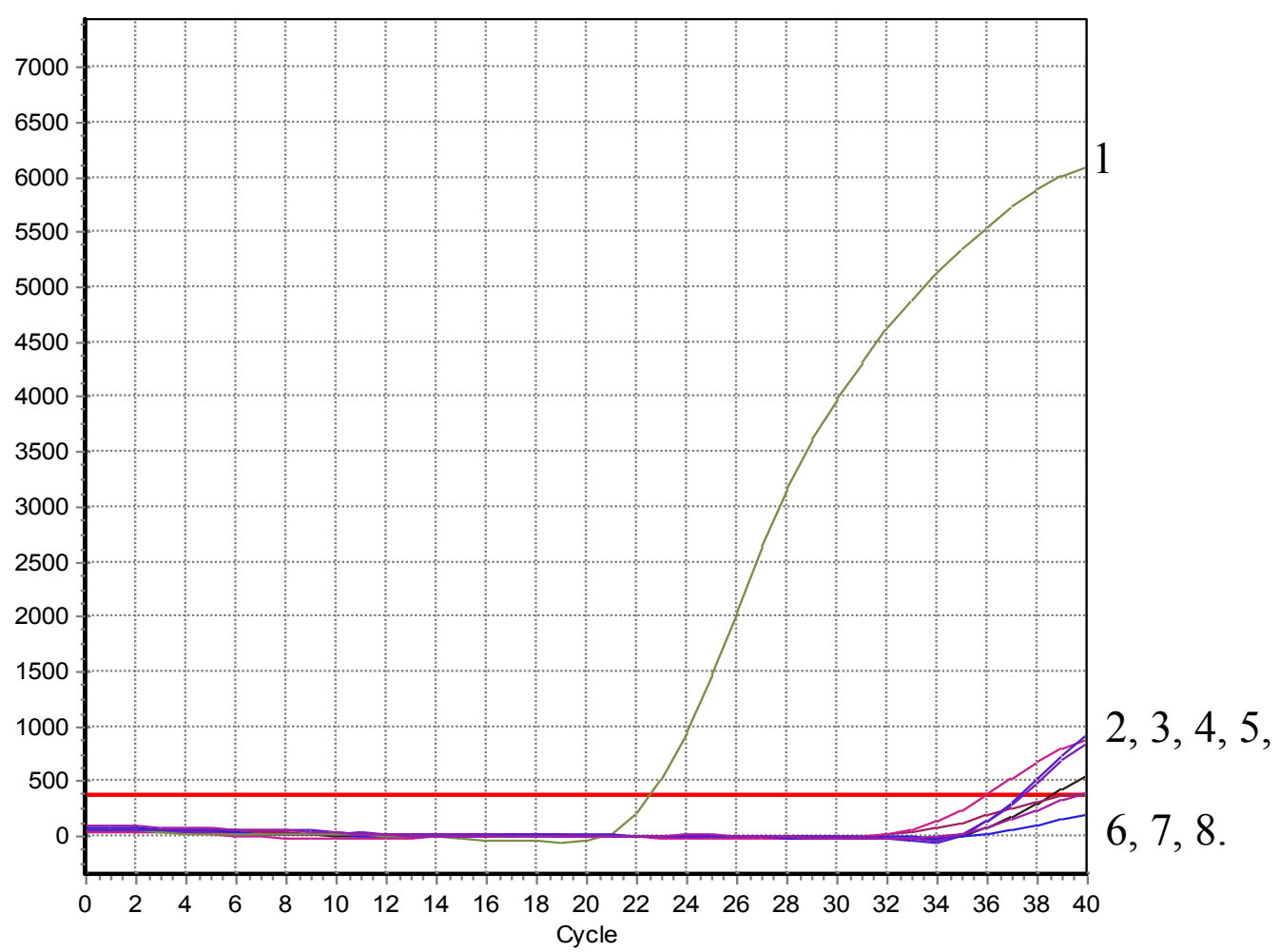

1. DTMUV

2. NDV

3. DPV

4. DPVV

5. DHV

6. AIV-H5

7. AIV-H9

8. Negative control

Figure 2 Real-time PCR specificity. The X-axis represents cycles, and the $Y$-axis represents the fluorescence data.

\section{Discussion}

Many methods such as histological examination, serological testing, virus isolation, and molecular assays are available for the diagnosis of flavivirus infections. Virus isolation is time consuming since it often requires 3-4 days. Histological examination and serological testing require specific antibodies to avoid serological crossreactivity between different viruses [5,6]. Because DTMUV is a newly emerged pathogen, developing a specific antibody against it will take time. To rapidly diagnose the infectious disease caused by DTMUV, molecular diagnostic methods such as reverse transcriptase PCR, reverse transcriptase real-time PCR, and loop- mediated isothermal amplification-all of which have been successfully used to diagnose other flaviviruses [6-11]-are useful for the epidemiological surveillance of DTMUV in China.

This paper describes a novel reverse transcriptase realtime PCR assay for DTMUV. The primers and probe were selected from the E gene of the DTMUV genome because this region is relatively conserved among DTMUV isolates. When the FXV and 5 other duck viruses were tested using real-time PCR, only the FXV tested positive. The results indicate that the real-time PCR assay is specific to DTMUV. In addition, the realtime PCR assay, including RNA extraction, took 

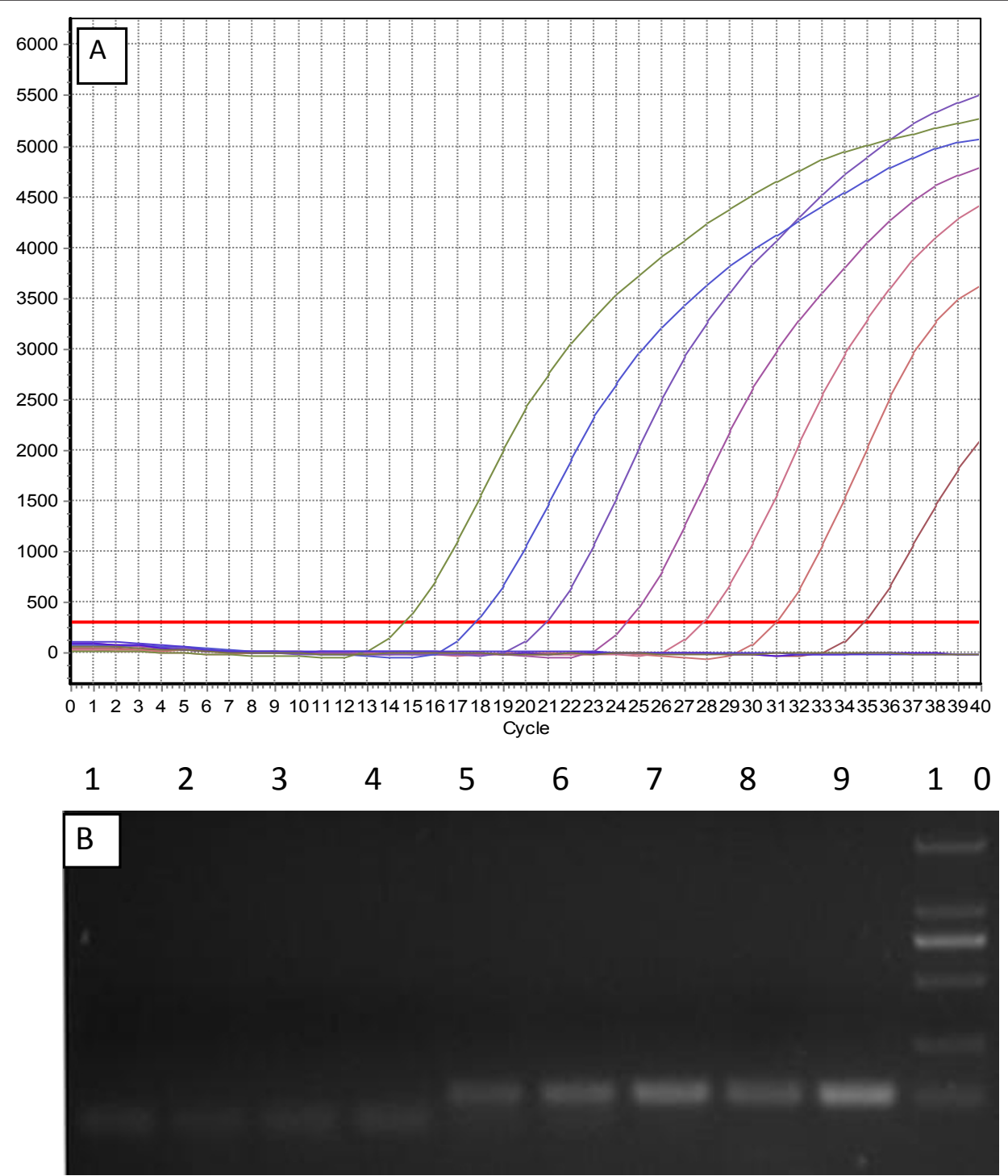

Figure 3 Comparison of the sensitivity of the real-time and conventional PCR. A. The sensitivity of the real-time PCR assay with the 10-fold dilution series of the standard plasmid DNA from $5 \times 10^{7}$ to $5 \times 10^{0}$ copies. The $X$-axis represents cycles, and the $Y$-axis represents the fluorescence data. The detection limit was 50 copies. B. Electrophoresis analysis of conventional PCR with EF and ER primers. Lane 1: $\mathrm{H}_{2} \mathrm{O}$ (control). Lanes 2-9: Amplification results of $5 \times 10^{0}$ to $5 \times 10^{7}$ template copies. Lane 10: DNA Marker DL2 000 .

approximately $3.5 \mathrm{~h}$, which is several hours or even days faster than conventional PCR and other virus isolation methods. Besides producing rapid results, reverse transcriptase real-time PCR has the advantages of sensitivity and efficiency for large-scale screening and virus quantification compared to conventional reverse transcriptase PCR [12-16]. Our newly established real-time PCR assay had a detection limit of 50 copies for DTMUV, which is 100 times more sensitive than conventional reverse transcriptase PCR. The method described

Table 1 Intra- and inter-assay reproducibility of the real-time PCR

\begin{tabular}{|c|c|c|c|c|c|c|c|}
\hline \multirow[t]{2}{*}{ Standard plasmids } & \multirow[t]{2}{*}{ Copies } & \multicolumn{3}{|c|}{ Intra-assay ( $C T$ Value) } & \multicolumn{3}{|c|}{ Inter-assay ( $C$ T value) } \\
\hline & & Mean & SD & $\mathrm{CV}(\%)$ & Mean & SD & $\mathrm{CV}(\%)$ \\
\hline 1 & $5.0 \times 10^{3}$ & 28.09 & 0.25 & $0.89 \%$ & 28.00 & 0.20 & $0.72 \%$ \\
\hline 2 & $5.0 \times 10^{4}$ & 24.56 & 0.15 & $0.61 \%$ & 24.68 & 0.14 & $0.57 \%$ \\
\hline 3 & $5.0 \times 10^{5}$ & 21.74 & 0.09 & $0.42 \%$ & 21.90 & 0.21 & $0.97 \%$ \\
\hline
\end{tabular}


Table 2 Virus detection from oropharyngeal and cloacal swabs of the experimentally infected ducks by real-time PCR and virus isolation

\begin{tabular}{|c|c|c|c|c|c|c|c|}
\hline \multirow[t]{3}{*}{ Samples } & \multirow[t]{3}{*}{ Days $\mathrm{PI}^{\mathrm{C}}$} & \multicolumn{3}{|c|}{ Oropharyngeal swabs } & \multicolumn{3}{|c|}{ Cloacal swabs } \\
\hline & & \multicolumn{2}{|c|}{ Real-time PCR } & \multirow[t]{2}{*}{ Virus isolation } & \multicolumn{2}{|c|}{ Real-time PCR } & \multirow[t]{2}{*}{ Virus isolation } \\
\hline & & $\mathrm{Ct}^{\mathrm{a}}$ & Result $^{b}$ & & $\mathrm{Ct}^{\mathrm{a}}$ & Result $^{b}$ & \\
\hline 1 & 2 & $>35$ & - & - & $>35$ & - & - \\
\hline 2 & 2 & $33.67 \pm 2.60$ & + & - & $33.58 \pm 0.61$ & + & + \\
\hline 3 & 3 & $33.59 \pm 0.05$ & + & - & $32.79 \pm 0.10$ & + & - \\
\hline 4 & 3 & $28.21 \pm 0.09$ & + & + & $28.37 \pm 0.19$ & + & - \\
\hline 5 & 5 & $32.06 \pm 0.29$ & + & + & $27.34 \pm 0.12$ & + & - \\
\hline 6 & 5 & $31.10 \pm 0.33$ & + & - & $25.46 \pm 0.22$ & + & + \\
\hline
\end{tabular}

(+): positive; (-): negative

${ }^{\text {a }} \mathrm{Ct}$ values obtained for the experiment are expressed as mean \pm standard deviation $(\mathrm{n}=3)$ if greater than zero.

${ }^{\mathrm{b}} \mathrm{Ct}<35$ was considered positive $(+)$.

c PI: post-inoculation.

Table 3 Virus detection from oropharyngeal and cloacal swabs of the contacted ducks by real-time PCR and virus isolation

\begin{tabular}{|c|c|c|c|c|c|c|c|}
\hline \multirow[t]{2}{*}{ Samples } & \multirow[t]{2}{*}{ Days $\mathrm{PC}^{\mathrm{C}}$} & \multicolumn{3}{|c|}{ Oropharyngeal swabs } & \multicolumn{3}{|c|}{ Cloacal swabs } \\
\hline & & $\mathrm{Ct}^{\mathrm{a}}$ & Result $^{b}$ & Virus isolation & $\mathrm{Ct}^{\mathrm{a}}$ & Result $^{\mathrm{b}}$ & Virus isolation \\
\hline 1 & 1 & $>35$ & - & - & $>35$ & - & - \\
\hline 2 & 1 & $32.48 \pm 0.84$ & + & - & $>35$ & - & - \\
\hline 3 & 2 & $33.14 \pm 0.57$ & + & - & $33.30 \pm 0.38$ & + & + \\
\hline 4 & 2 & $29.87 \pm 0.10$ & + & - & $32.11 \pm 0.74$ & + & - \\
\hline 5 & 4 & $30.32 \pm 0.12$ & + & - & $29.92 \pm 0.04$ & + & + \\
\hline 6 & 4 & $30.93 \pm 0.19$ & + & + & $27.34 \pm 0.12$ & + & - \\
\hline
\end{tabular}

,$+-{ }^{\mathrm{a}}$, and ${ }^{\mathrm{b}}$ have the same meanings as in Table 2 .

c PC: post-contact.

Table 4 Quantification of DTMUV in tissue samples by real-time PCR $^{\mathrm{a}}$ and virus isolation ${ }^{\mathrm{b}}$

\begin{tabular}{|c|c|c|c|c|c|c|c|c|}
\hline \multirow[t]{2}{*}{ Samples } & \multicolumn{2}{|c|}{ Duck 1} & \multicolumn{2}{|c|}{ Duck 2} & \multicolumn{2}{|c|}{ Duck 3} & \multicolumn{2}{|c|}{ Duck 4} \\
\hline & Real-time PCR & Virus isolation $^{\mathbf{b}}$ & Real-time PCR & $\begin{array}{c}\text { Virus } \\
\text { isolation }^{\text {b }}\end{array}$ & Real-time PCR & Virus isolation $^{b}$ & Real-time PCR & Virus isolation $^{b}$ \\
\hline Blood & $6.56 \pm 0.06$ & 2.50 & $4.46 \pm 0.36$ & 0.98 & - & - & $6.80 \pm 0.03$ & 1.25 \\
\hline Liver & $4.88 \pm 0.03$ & - & $4.53 \pm 0.08$ & - & $5.54 \pm 0.05$ & 0.97 & $6.66 \pm 0.02$ & 2.17 \\
\hline Lungs & $5.49 \pm 0.04$ & 2.75 & $5.02 \pm 0.01$ & 1.38 & $6.11 \pm 0.02$ & 3.25 & $6.48 \pm 0.01$ & 3.50 \\
\hline Kidneys & $5.01 \pm 0.02$ & 1.75 & $4.02 \pm 0.06$ & - & $5.49 \pm 0.15$ & 3.50 & $5.42 \pm 0.05$ & 2.75 \\
\hline Brain & - & & $5.04 \pm 0.06$ & 1.75 & $5.43 \pm 0.01$ & 2.50 & $6.50 \pm 0.08$ & 2.25 \\
\hline Pancreas & $6.75 \pm 0.04$ & 2.25 & $6.91 \pm 0.01$ & 2.50 & $7.52 \pm 0.02$ & 1.67 & $7.56 \pm 0.02$ & 3.25 \\
\hline
\end{tabular}

(-): Negative results with the real-time PCR or virus isolation assay.

Ducks 1 and 2 were inoculated intranasally with $10^{5}$ ELD $_{50}$ FXV and euthanized 4 and 7 days post-inoculation, respectively.

Ducks 3 and 4 were introduced into the isolator, placed with the intranasally inoculated ducks, and euthanized 6 days post-contact.

a Unit: log 10 copies/mL for blood and log 10 copies/g for other tissue samples.

${ }^{b}$ Unit: $\log 10 E L D_{50} / \mathrm{mL}$ for blood and log $10 \mathrm{ELD}_{50} / \mathrm{g}$ for other tissue samples.

here is sufficiently sensitive and specific for the diagnosis of DTMUV in both artificially and naturally infected ducks.

\section{Conclusions}

We described an easy, fast, and a reliable diagnostic method that can detect and quantify newly emerged
DTMUV by using a reverse transcriptase real-time PCR assay.

\section{Abbreviations}

AIV: avian influenza virus; Ct: cycle threshold; CV: Coefficients of variation; DHV: duck hepatitis virus; DPV: duck plague virus; DPW: duck parvovirus; DTMUV: duck Tembusu virus; FXV: Fengxian virus; NDV: Newcastle disease virus; PBS: phosphate-buffered saline; PC: post-contact; PI: post-inoculation 


\section{Acknowledgements}

This study was supported by the Shanghai Pujiang Talent Program, China (no. 09PJ1411900); the Ministry of Agriculture's Major Projects for Transgenic Research Program, China (no. 2009ZX08010-022B); the Special Fund for Agro-scientific Research in the Public Interest, China (no. 201003012); the Postdoctoral Science Foundation of China (no. 20090450475); and the Special Fund for international communication and cooperation (no. S2011ZR0429).

We would like to thank Guangqing Liu for providing the duck plague virus, duck hepatitis virus, and duck parvovirus used in this study.

\section{Authors' contributions}

$\mathrm{ZJ}$ designed the probe and primers and revised the manuscript. LPY wrote the manuscript and carried out the experiments with the help of PXY who carried out virus isolation, JWZ who extracted RNA from the samples, and QYT who participated in the sequence alignment. All the authors have read and approved the final manuscript.

\section{Competing interests}

The authors declare that they have no competing interests.

Received: 21 April 2011 Accepted: 7 October 2011

Published: 7 October 2011

\section{References}

1. Yan P, Zhao Y, Zhang X, Xu D, Dai X, Teng Q, Yan L, Zhou J, Ji X, Zhang S, et al: An infectious disease of ducks caused by a newly emerged Tembusu virus strain in mainland China. Virology 2011, 417:1-8.

2. Teng Q, Pixi Yan, Xu Zhang, Liping Yan, Zejun Li: A novel flavivirus causing duck egg drops and death. Chin J Anim Infect Dis 2010, 18(6):1-4.

3. Su J, Li S, Hu X, Yu X, Wang Y, Liu P, Lu X, Zhang G, Liu D, Li X, et al: Duck egg-drop syndrome caused by BYD virus, a new Tembusu-related flavivirus. PLoS One 2011, 6:e18106.

4. Parida MM, Santhosh SR, Dash PK, Tripathi NK, Lakshmi V, Mamidi N, Shrivastva A, Gupta N, Saxena P, Babu JP, et al: Rapid and real-time detection of Chikungunya virus by reverse transcription loop-mediated isothermal amplification assay. J Clin Microbiol 2007, 45:351-357.

5. Matthews V, Robertson T, Kendrick T, Abdo M, Papadimitriou J, McMinn P: Morphological features of Murray Valley encephalitis virus infection in the central nervous system of Swiss mice. Int J Exp Pathol 2000, 81:31-40.

6. Chao DY, Davis BS, Chang GJ: Development of multiplex real-time reverse transcriptase PCR assays for detecting eight medically important flaviviruses in mosquitoes. J Clin Microbiol 2007, 45:584-589.

7. Lambert AJ, Martin DA, Lanciotti RS: Detection of North American eastern and western equine encephalitis viruses by nucleic acid amplification assays. J Clin Microbiol 2003, 41:379-385.

8. Kang X, Li Y, Liu H, Lin F, Cai X, Sun T, Chang G, Zhu Q, Yang Y: A duplex real-time reverse transcriptase polymerase chain reaction assay for detecting western equine and eastern equine encephalitis viruses. Virol $J$ 2010, 7:284.

9. Parida M, Posadas $G$, Inoue $S$, Hasebe F, Morita K: Real-time reverse transcription loop-mediated isothermal amplification for rapid detection of West Nile virus. J Clin Microbiol 2004, 42:257-263.

10. Igarashi A, Tanaka M, Morita K, Takasu T, Ahmed A, Ahmed A, Akram DS, Waqar MA: Detection of west Nile and Japanese encephalitis viral genome sequences in cerebrospinal fluid from acute encephalitis cases in Karachi, Pakistan. Microbiol Immunol 1994, 38:827-830.

11. Pyke AT, Smith IL, van den Hurk AF, Northill JA, Chuan TF, Westacott AJ, Smith GA: Detection of Australasian Flavivirus encephalitic viruses using rapid fluorogenic TaqMan RT-PCR assays. J Virol Methods 2004, 117:161-167.

12. D'Haene B, Vandesompele J, Hellemans J: Accurate and objective copy number profiling using real-time quantitative PCR. Methods 2010, 50:262-270.

13. Garson JA, Grant PR, Ayliffe U, Ferns RB, Tedder RS: Real-time PCR quantitation of hepatitis $B$ virus DNA using automated sample preparation and murine cytomegalovirus internal control. J Virol Methods 2005, 126:207-213.

14. Stordeur P: Monitoring the immune response using real-time PCR. Methods Mol Biol 2009, 496:323-338.
15. Parida MM: Rapid and real-time detection technologies for emerging viruses of biomedical importance. J Biosci 2008, 33:617-628.

16. Palmisano L, Giuliano M, Nicastri E, Pirillo MF, Andreotti M, Galluzzo CM, Bucciardini R, Fragola V, Andreoni M, Vella S: Residual viraemia in subjects with chronic HIV infection and viral load < 50 copies/ml: the impact of highly active antiretroviral therapy. Aids 2005, 19:1843-1847.

doi:10.1186/1743-422X-8-464

Cite this article as: Yan et al:: Establishing a TaqMan-Based Real-Time PCR Assay for the rapid detection and quantification of the newly emerged duck tembusu virus. Virology Journal 2011 8:464.

\section{Submit your next manuscript to BioMed Central and take full advantage of:}

- Convenient online submission

- Thorough peer review

- No space constraints or color figure charges

- Immediate publication on acceptance

- Inclusion in PubMed, CAS, Scopus and Google Scholar

- Research which is freely available for redistribution

Submit your manuscript at www.biomedcentral.com/submit
Ciomed Central 